\title{
Lobular Breast Cancer in a Male Patient with a Previous History of Irradiation Due to Hodgkin's Disease
}

\author{
Srdjan Ninkovic ${ }^{a, b} \quad$ Goran Azanjac $^{b} \quad$ Milan Knezevic $^{a, b} \quad$ Dragce Radovanovic ${ }^{a, b}$ \\ Dragan Canovic ${ }^{a, b}$ Jasmina Nedovic ${ }^{b}$ Slobodanka Mitrovic ${ }^{a, b}$
}

aFaculty of Medicine, University of Kragujevac,

${ }^{\mathrm{b} C l i n i c a l}$ Centre Kragujevac, Serbia

\section{Keywords}

Male breast cancer - Histology .

Immunohistochemistry · Pathology

\section{Summary}

Background: Male breast cancer is rare and represents less than $1 \%$ of all breast cancers. Considering the fact that the male breast most often does not consist of lobules and acini, lobular carcinoma of the male breast is exceptionally rare. Case Report: In this paper we present a unique case of alveolar variant of lobular male breast cancer in a 56-year-old patient. Conclusion: According to our knowledge this is the first presentation of an alveolar variant of lobular male breast cancer that appeared 14 years after chemo- and radiotherapy for the treatment of Hodgkin's disease.

\section{Introduction}

Male breast cancer accounts for less than $1 \%$ of all breast cancers and less than $1 \%$ of all male cancer deaths [1]. Due to the fact that the male breast most often does not consist of lobules and acini, lobular carcinoma of the male breast is exceptionally rare [2]. Approximately 20 cases have been reported so far all of which were of the classical subtype (table 1) [3-18], with the exception of 1 case which showed a histological picture of pleomorphic lobular cancer [19]. In this article, we present a male patient with the alveolar variant of lobular cancer, proved immunohistochemically by an E-cadherin-negative result.

\author{
Schlüsselwörter \\ Brustkrebs des Mannes · Histologie . \\ Immunhistochemie $\cdot$ Pathologie
}

\section{Zusammenfassung}

Hintergrund: Brustkrebs des Mannes ist selten und macht weniger als $1 \%$ aller Mammakarzinome aus. Aufgrund der Tatsache, dass die männliche Brust in der Regel nicht aus Lobuli und Acini besteht, sind lobuläre Karzinome der männlichen Brust äußerst selten. Fallbericht: Wir stellen hiermit den außergewöhnlichen Fall einer alveolären Variante lobulären männlichen Brustkrebses bei einem 56-jährigen Patienten vor. Schlussfolgerung: Unseres Wissens ist dies der erste Fall einer alveolären Variante lobulären männlichen Brustkrebses, der 14 Jahre nach chemo- und radiotherapeutischer Behandlung eines Morbus Hodgkin entstanden war.

\section{Case Report}

A 56-year-old male patient was admitted with changes to the central quadrant of the right breast, which he had noticed 1 month earlier. He was married with 2 healthy children, and worked as a manager in a primary school. The patient did not report any trauma, liver disorders, gynecomastia, or use of hormones and other drugs. However, he had suffered from Hodgkin's lymphoma, a type of nodular sclerosis, 14 years ago. The disease had reached the second clinical stage, and was localized in the right supraclavicular and cervical lymph nodes. The treatment had consisted of ABVD (doxorubicin, bleomycin, vinblastine, dacarbazine) chemotherapy and radiotherapy, after which a complete remission was achieved. To this day the patient has remained relapse-free as verified by hematology reports from regular control examinations.

During clinical examination the presence of a firm, painless, mobile, subareolar tumor mass the size of a small nut was noted in the central quadrant of the right breast, with no retraction of the skin. Axillary lymph nodes were not palpable. On ultrasound examination the lesion measured $22 \mathrm{~mm}$ in diameter, had unclear boundaries, and showed pathological

\section{KARGER}

Fax +497614520714

Information@Karger.de

www.karger.com
(C) 2012 S. Karger GmbH, Freiburg

$1661-3791 / 12 / 0074-0315 \$ 38.00 / 0$

Accessible online at:

www.karger.com/brc
Slobodanka Mitrović MD, PhD

Department of Pathology, Faculty of Medicine, University of Kragujevac

Centre for Pathology, Clinical Centre Kragujevac

69 Svetozar Markovic Street, Kragujevac 34000, Serbia

Tel. +381 34-505356, Fax -306800(112)

smitrovic@medf.kg.ac.rs 
Table 1. Review of cases of lobular male breast cancer in the literature

\begin{tabular}{|c|c|c|c|c|c|c|}
\hline Authors [ref.] & Year & $\begin{array}{l}\text { Cases, } \\
\mathrm{n}\end{array}$ & $\begin{array}{l}\text { Age, } \\
\text { years }\end{array}$ & Side & Lobular carcinoma (subtype) & TNM status \\
\hline Norris et al. [3] & 1969 & 1 & $?$ & unknown & small cell carcinoma & unknown \\
\hline Giffler and Kay [4] & 1976 & 2 & $67 / 74$ & left/left & small cell carcinoma/small cell carcinoma & TxNoMo/TxNoMo \\
\hline Yogore and Sahgal [5] & 1977 & 1 & 56 & left & small cell carcinoma & T2NoMo \\
\hline Sanchez et al. [6] & 1986 & 1 & 61 & left and right & classic subtype & TxNoMx \\
\hline Nance and Reddick [7] & 1989 & 1 & 82 & right & classic subtype & unknown \\
\hline Sawabe et al. [8] & 1992 & 1 & 74 & unknown & classic subtype & unknown \\
\hline Michaels et al. [9] & 1994 & 1 & 59 & right & classic subtype & TxNoMo \\
\hline Yamamoto et al. [10] & 1997 & 1 & 68 & left & classic subtype & T4NxM1 \\
\hline San Miguel et al. [11] & 1997 & 1 & 62 & left & classic subtype & unknown \\
\hline Scheidbach et al. [12] & 2000 & 1 & 85 & right & classic subtype & T4N2Mo \\
\hline Koc et al. [13] & 2001 & 1 & 52 & right & classic subtype & T2NoMo \\
\hline Chandrasekharan et al. [14] & 2001 & 2 & $53 / 73$ & left/right & classic subtype/classic subtype & T2N1Mo/T2N1Mo \\
\hline Maly et al. [19] & 2005 & 1 & 44 & left & pleomorphic subtype & T2NoMo \\
\hline Mardi and Sharma [15] & 2006 & 1 & 56 & left & classic subtype & unknown \\
\hline Erhan et al. [16] & 2006 & 1 & 64 & left & classic subtype & T2NoMo \\
\hline Spencer and Shutter [17] & 2008 & 1 & 58 & left and right & classic subtype & T4NxM1 \\
\hline
\end{tabular}
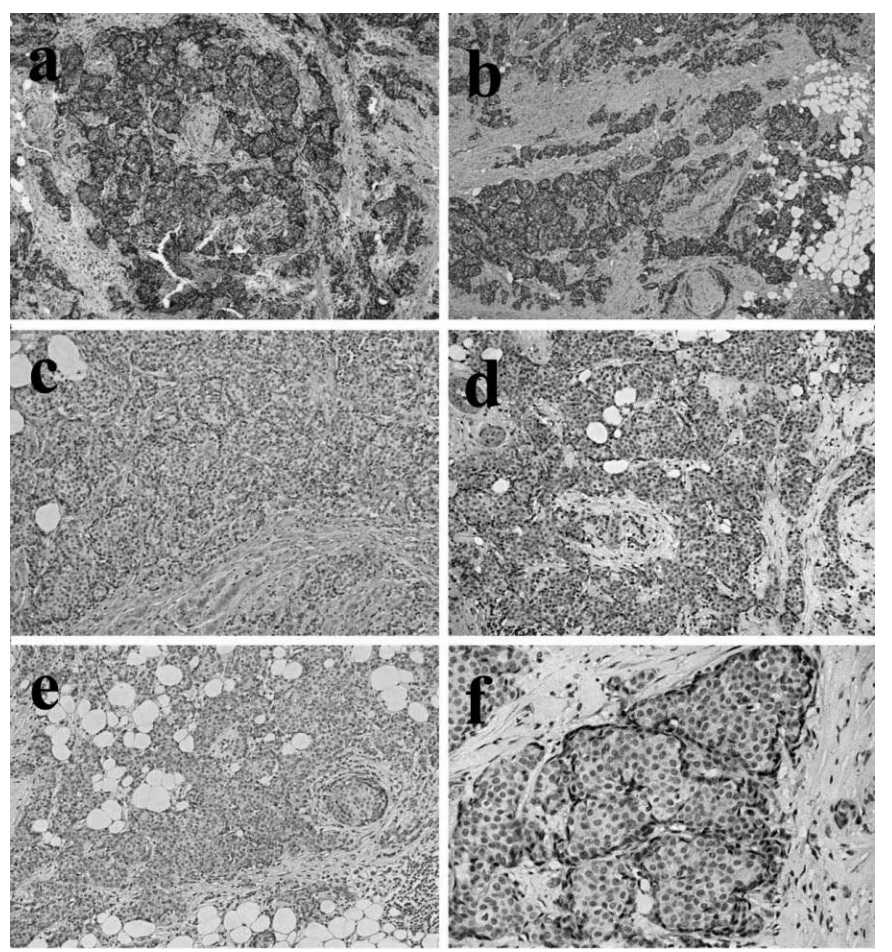

Fig. 1. a Invasive lobular carcinoma, alveolar subtype (hematoxylin and eosin stain; original magnification $\times 100$ ). b Tumor cells were strongly positive (score 8 ) for estrogen receptor (ER immunostaining with hematoxylin counterstain, original magnification $\times 100)$. c Tumor cells were weak-to-moderately positive (score 4-5) for progesterone receptor (PR immunostaining with hematoxylin counterstain, original magnification $\times 200$ ). d Tumor cells were negative for Her-2 receptors (Her-2 immunostaining with hematoxylin counterstain, original magnification $\times 200$ ). e Complete loss of E-cadherin expression in lobular cancer cells (E-cadherin immunostaining with hematoxylin counterstain, original magnification $\times 200)$. $\mathbf{f}$ Myoepithelial cells were positive for E-cadherin in foci of lobular in situ carcinoma (E-cadherin immunostaining with hematoxylin counterstain, original magnification $\times 400$ ). vascularization zones and distal weakness of the ultrasound signal. Oncologists staged the tumor as T2N0M0 and recommended surgical treatment. After excision of the tumor and intraoperative frozen section histological analysis, a malignant process was confirmed and mastectomy and axillary lymph node dissection performed. A total of 14 lymph nodes were examined, and none revealed metastatic deposits. No complications were observed in the postoperative period, and after 5 days the patient was discharged from hospital in good condition. Further treatment consisted of radiation therapy and chemotherapy in 6 cycles according to the FAC protocol (cyclophosphamide, adriamycin, 5-fluorouracil), and tamoxifen (20 mg daily). 2 years after the surgery, the patient is alive without any residual or metastatic disease.

\section{Pathohistological Findings}

Analysis of tumor tissue included a sample of yellowish color and irregular shape, measuring $42 \mathrm{~mm}$ in diameter. Cross section showed a whiteyellowish change with circumscribed edges and of firm consistency, measuring $21 \times 18 \mathrm{~mm}$. Several samples were taken of which 2 were prepared at cryostatic condition for ex tempore analysis; others were fixed for $24 \mathrm{~h}$ in $4 \%$ formaldehyde and paraffin-embedded. Paraffin blocks were cut into 5- $\mu \mathrm{m}$ sections, stained with hematoxylin and eosin, and immunohistochemically analyzed at a later stage. Microscopically the tumor showed the histological picture of an alveolar variant of lobular carcinoma with relatively uniform cells (fig. 1 a), light cytoplasm, regular round nuclei, cell nests and alveolar arrangements, desmoplastic reaction, and scarce lymphocytic infiltration. An in situ component was present. Immunohistochemically the tumor cells showed strong positivity (score 8) for estrogen receptors (fig. 1 b), weak-to-moderate positivity (score 4-5) for progesterone receptors (fig. $1 \mathrm{c}$ ), and negativity for Her-2 receptors (fig. 1 d). The cytoplasmic membrane did not stain for E-cadherin (figs. 1 e and f), and the Ki-67 proliferation index was very low (2\%).

\section{Discussion}

Male breast cancer is extremely rare (less than $1 \%$ of all breast cancers) and usually appears at an older age $(>60$ years). The most frequent histology types are ductal invasive carcinoma (around 93\%) and papillary carcinoma (3\%) [2]. In a large series from France investigating male breast cancer (397 cases from different regional centers, 1970-1992), ductal invasive carcinoma was present in $97 \%$, while other cases 
represented in situ changes [20]. Burga et al. [18] in their study of 759 archived cases of primary invasive carcinoma involving the male breast, revealed that $84.7 \%$ were pure infiltrating ductal carcinoma and $0.4 \%$ pure lobular carcinoma.

Analysis of the histological features of male breast cancer as compared to female breast cancer indicates the presence of only 1 difference: lobular (also known as small-cell) cancer is extremely rare in men due to hormonal factors and the lack of acini and lobules [3-5]. However, although true lobule formation is not usually present, lobules are sometimes seen, but there is disagreement as to whether this feature occurs only in cases with a known endocrine etiology [20-22].

Some studies have compared the stages of breast cancer in male patients with those in female patients, indicating that there was no significant difference in survival time and clinical course [23, 24]. In contrast the results of other studies showed that male breast cancers can be more aggressive and have a worse prognosis $[25,26]$. Scarcity of breast tissue, small distance between the skin and the areola, richness in dermal lymphatic vessels, early regional and distant metastasis, and late diagnosis probably are reasons for this [27]. Particularly the poorer prognosis of male patients is primarily connected to the disease being diagnosed at a later stage compared to women, at which stage lymph node involvement is found in more that $60 \%$ of the patients [28].

In our patient, the tumor cells showed estrogen and progesterone receptor positivity. Studies show that although most male breast cancers are estrogen-positive, they have no prognostic advantage compared to women [29], and the reason for this is thought to be the commonly higher clinic disease stage in male patients [30]. Furthermore, male breast cancers show much less p53 positivity and overexpression of Her-2 receptors [31]. Immunohistochemical staining for E-cadherin helps in differentiating the histology of male breast cancers; moderate to intense membrane expression is present in $85 \%$ of ductal cancers, while the lobular variant shows total negativity for E-cadherin [32-34]. All reported cases of lobular carcinoma of the male breast have met the established histomorphological criteria, with the exception of the pleomorphic variant which demonstrates negative immunohistochemical staining for E-cadherin [19].

Overall male breast cancer has a low incidence, and hence its etiopathogenesis, immunophenotype, and clinical course have been much less investigated than female breast cancer. Numerous studies have confirmed clear genetic differences so that the poorer prognosis may be related to a lesser efficacy of available therapies irrespective of the differences in the biological profile of male and female breast cancer [35, 36]. Numerous factors are associated with higher risk in male breast cancer. The most frequently reported are family history of breast cancer [37] and genetic factors [38]. Eldar et al. [39] described 10 cases of breast cancer appearing after chest irradiation. Other suggested contributing factors are Klinefelter's syndrome [6, 14], gynecomastia, obesity, clinical conditions causing hypoandrogenism (testicular trauma and infertility), and liver diseases causing hyperestrogenism [38]. Together with endocrine disorders, long-lasting use of certain drugs can cause proliferation of lobular structures, which is the main predisposing factor for the lobular variant of male breast cancer [11].

Our patient is a phenotypically and genotypically proven male, with no use of drugs with estrogen activity (e.g. hormone therapy, cimetidine) or intrinsic conditions causing a hyperestrogenic state (cirrhosis or other liver diseases). His family history did not include malign breast diseases in either female or male relatives. Prior to Hodgkin's disease, which was treated with cytotoxic agents and radiation therapy, the patient had been completely healthy. Therefore, the only risk factor that could be responsible for the appearance of this extremely rare male disease is radiation therapy for previous disease. According to the literature and our findings, this is the first presentation of an alveolar variant of lobular male breast cancer with negative staining for E-cadherin.

\section{Disclosure Statement}

The authors declare that they do not have competing interests.

\section{References}

$>_{1}$ Fentiman IS, Fourquet A, Hortobagyi GN: Male breast cancer. Lancet 2006;367:595-604.

2 O'Malley CD, Prehn AW, Shema SJ, Glaser SL: Racial/ethnic differences in survival rates in a population-based series of men with breast carcinoma. Cancer 2002;94:2836-43.

3 Norris HJ, Taylor HB: Carcinoma of the male breast. Cancer 1969;23:1428-35.

4 Giffler RF, Kay S: Small-cell carcinoma of the male mammary gland: a tumour resembling infiltrating lobular carcinoma. Am J Clin Pathol 1976;66:71522.

5 Yogore MG, Sahgal S: Small cell carcinoma of the male breast: report of a case. Cancer 1977;39:174851 .
6 Sanchez AG, Villanueva AG, Redondo C: Lobular carcinoma of the breast in a patient with Klinefelter's syndrome. A case with bilateral, synchronous, histologically different breast tumors. Cancer 1986;57:1181-3.

7 Nance KV, Reddick RL: In situ and infiltrating lobular carcinoma of the male breast. Hum Pathol 1989;20:1220-2.

8 Sawabe Y, Shinoda M, Osawa J, et al: Lobular carcinoma of the male breast - a case report. Nippon Geka Gakkai Zasshi 1992;93:442-4.

9 Michaels BM, Nunn CR, Roses DF: Lobular carcinoma of the male breast. Surgery 1994;115:402-5.

10 Yamamoto T, Iriyama K, Araki T: Male inflammatory breast cancer. Surg Today 1997;27:669-71.
11 San Miguel P, Sancho M, Enriquez JL, Fernandez J, Gonzalez-Palacios F: Lobular carcinoma of the male breast associated with the use of cimetidine. Virchows Arch 1997;430:261-3.

12 Scheidbach H, Dworak O, Schmucker B, Hohenberger W: Lobular carcinoma of breast in an 85-year-old man. Eur J Surg Oncol 2000;26:31921.

13 Koc M, Oztas S, Erem TM, Ciftcioglu AM, Onuk DM: Invasive lobular carcinoma of the male breast: a case report. Jpn J Clin Oncol 2001;31:444-6.

14 Chandrasekharan S, Fasanya C, Macneill FA: Invasive lobular carcinoma of the male breast: do we need to think of Klinefelter's syndrome? Breast 2001;10:176-8. 
15 Mardi K, Sharma J: Invasive lobular carcinoma of male breast - a case report. Indian J Pathol Microbiol 2006;49:272-4.

16 Erhan Y, Zekioglu O, Erhan Y: Invasive lobular carcinoma of the male breast. Can J Surg 2006 49:365-6.

17 Spencer JT, Shutter J: Synchronous bilateral invasive lobular breast cancer presenting as carcinomatosis in a male. Am J Surg Pathol 2009;33:470-4.

-18 Burga A, Fadare O, Lininger RA, Tavassoli FA: Invasive carcinomas of the male breast: a morphologic study of the distribution of histologic subtypes and metastatic patterns in 778 cases. Virchows Arch 2006;449:507-12.

19 Maly B, Maly A, Pappo I, Meir K, Pappo O: Pleomorphic variant of invasive lobular carcinoma of the male breast. Virchows Arch 2005;446:344-5.

20 Anderson JA, Gram JB: Gynaecomasty. Histological aspects in a surgical material. Acta Pathol Microbiol Immunol Scand (A) 1982;90:185-90.

21 Kanhai RC, Hage JJ, van Diest PJ, Bloemena E, Mulder JW: Short-term and long-term histologic effects of castration and estrogen treatment on breast tissue of 14 male-to-female transsexuals in comparison with two chemically castrated men. Am J Surg Pathol 2000;24:74-80.

-22 Shin SJ, Rosen PP: Bilateral presentation of fibroadenoma with digital fibroma-like inclusions in the male breast. Arch Pathol Lab Med 2007;131: 1126-9.
23 Cutuli B, Lacroze M, Dilhuydy JM, et al.: Male breast cancer: results of treatments and prognostic factors in 397 cases. Eur J Cancer 1995;12:1960-4.

24 Borgen PI, Senie RT, McKinnon WM, Rosen PP: Carcinoma of the male breast: analysis of prognosis compared with matched female patients. Ann Surg Oncol 1997:4:385-8.

25 Joshi MG, Lee AK, Loda M, et al.: Male breast carcinoma: an evaluation of prognostic factors contributing to a poorer outcome. Cancer 1996:177: 490-8.

26 Kidwai N, Gong Y, Sun, et al.: Expression of androgen receptor and prostate-specific antigen in male breast carcinoma. Breast Cancer Res 2004; 6:R18-R23.

27 Salvadori B, Saccozzi R, Manzari A, et al.: Prognosis of breast cancer in males: an analysis of 170 cases. Eur J Cancer 1994;30:930-5.

28 Goyal A, Horgan K, Kissin M, et al.: Sentinel lymph node biopsy in male breast cancer patients. Eur J Surg Oncol 2004;30: 480-3.

29 Munoz de Toro MM, Maffini MV, Kass L, Luque EH: Proliferative activity and steroid hormone receptor status in male breast carcinoma. J Steroid Biochem Mol Biol 1998;67:333-9.

30 Rayson D, Erlichman C, Suman VJ, et al.: Molecular markers in male breast carcinoma. Cancer 1998;83:1947-55.

31 Muir D, Kanthan R, Kanthan SC: Male versus female breast cancers. A population-based comparative immunohistochemical analysis. Arch Pathol Lab Med 2003;127:36-41.
32 Moll R, Mitze M, Frixen UH, Brichmeier W: Differential loss of E-cadherin expression in infiltrating ductal and lobular breast carcinomas. Am J Pathol 1993;43:1731-2.

33 Acs G, Lawton TJ, Rebbeck TR, et al.: Differential expression of E-cadherin in lobular and ductal neoplasms of the breast and its biologic and diagnostic implications. Am J Clin Pathol 2001;115:85-98.

34 Mastracci TL, Boulos FI, Andrulis IL, Lam WL: Genomics and premalignant breast lesions: clues to the development and progression of lobular breast cancer. Breast Cancer Res 2007;9:215.

35 Barlund M, Kuukasjarvi T, Syrjakoski K, Auvinen A, Kallioniemi A: Frequent amplification and overexpression of CCND1 in male breast cancer. Int J Cancer 2004;111:968-71.

36 Petroni S, Mangia A, D’Amico C, Simone G Expression of steroid receptors and DNA synthesis in male breast cancer. Pathologica 2003;95:31-6.

37 Anderson DE, Badzioch MD: Breast cancer risks in relatives of male breast cancer patients. J Natl Cancer Inst 1992;84:1111-7.

38 Weiss JR, Moysich KB, Swede H: Epidemiology of male breast cancer. Cancer Epidemiol Biomarkers Prev 2005;14:20-6.

39 Eldar S, Nash E, Abrahamson J: Radiation carcinogenesis in the male breast. Eur J Surg Oncol 1989;15:274-8. 